\title{
Construction of Electrocatalytic Electrodes Bearing the Triphenylamine Nucleus Covalently Bound to Carbon. A Halogen Dance in Protonated Aminotriphenylamines.
}

\author{
Brian T. Mayers and Albert J. Fry* \\ Chemistry Department, Wesleyan University, Middletown, CT 06459 \\ SUPPORTING INFORMATION
}

Table of Contents

General procedures

S-2

4-Nitrotriphenylamine (2)

S-2

4-Nitro-4',4"'-dibromotriphenylamine (3)

S-3

Halogen dance with 4-Amino-4',4"-dibromotriphenylamine (4c)

Diazotization of the mixture of amines produced at $75^{\circ} \mathrm{C}$

S-4

4-Aminotriphenylamine (4a)

S-4

Diazotization of 4-Aminotriphenylamine

S-4

Attachment of triphenylamines to carbon fiber electrodes

S-5

Representative preparative electrolysis

S-6 
General: ${ }^{1} \mathrm{H}$ NMR spectra were recorded in $\mathrm{CDCl}_{3}$ on a Varian $300 \mathrm{MHz}$ Gemini spectrometer. Mass spectra were recorded on a Hewlett-Packard model 59988A gas chromatograph- mass spectrometer. Preparative scale chromatography was carried out on a medium pressure liquid chromatography system using Merck $310 \mathrm{~mm}$ x $25 \mathrm{~mm}$ silica Lichroprep columns, eluting with an 85:15 hexane:ethyl acetate mixture. Melting points were determined using a Mel-Temp apparatus (Scientific Devices Co.). Electrochemical measurements were made on a Princeton Applied research Versastat potentiostat using the Model 270/250 electrochemistry software.

4-Nitrotriphenylamine (2). To a solution of triphenylamine $(2.455 \mathrm{~g}, 0.010 \mathrm{~mol})$ in 50 $\mathrm{mL}$ of acetic anhydride was added $1.897 \mathrm{~g}$ copper(II) nitrate $(0.010 \mathrm{~mol})$ with stirring. The solution was stirred at room temperature for 2 hours, during which time the color changed from blue to dark green/blue. Water $(100 \mathrm{~mL})$ and chloroform $(15 \mathrm{~mL})$ were added to the flask and stirring was continued for an additional 12 hours. The layers were separated and the aqueous layer was extracted with two $20 \mathrm{~mL}$ portions of chloroform. The combined organic layers were washed with $100 \mathrm{~mL}$ of water, dried over magnesium sulfate, filtered, and evaporated to afford yellow/orange crystals. Analysis by GC-MS indicated the presence of three compounds. In order of GC retention time these were identified as 4-nitrotriphenylamine (2) (54\%) [m/e = 290], 4,4'-dinitrotriphenylamine $(8 \%)[m / e=335]$, and 4,4',4"-trinitrotriphenylamine $(38 \%)[m / e=380]$. Compound 2 was readily separated in pure form (200 mg per run) by medium pressure liquid chromatography at 80 psi; yield $1.192 \mathrm{~g}$ (isolated yield $41 \%$ ), mp $141^{\circ}{ }^{-142^{\circ}}$ (lit. ${ }^{1} 141.5$ $\left.142^{\circ}\right)$.

1. Bergstrom, F. W.; Granara, I. M.; Erickson, V. J. Org. Chem. 1942, 798. 
4-Nitro-4',4"-dibromotriphenylamine (3). To a solution of 4-nitrotriphenylamine (2) (0.641 g, $2.21 \mathrm{mmol})$ in $18 \mathrm{~mL}$ of $\mathrm{CH}_{2} \mathrm{Cl}_{2}$ was added a solution of $\mathrm{Br}_{2}(6.0 \mathrm{~g}, 37.5 \mathrm{mmol})$ in $\mathrm{CH}_{2} \mathrm{Cl}_{2}$. The solution immediately became dark yellow/brown. It was stirred for 36 hours, then quenched with $50 \mathrm{~mL}$ of $4 \%$ aqueous sodium bisulfite. The organic layer was washed with two $25 \mathrm{~mL}$ portions of $4 \%$ sodium bisulfite and one of water. After drying over $\mathrm{MgSO}_{4}$, filtration, and evaporation, compound $\mathbf{3}$ was isolated as red/orange flakes, $0.983 \mathrm{~g}(99 \%)$, homogeneous by tlc and GC-MS. The ${ }^{1} \mathrm{H}$ NMR spectrum was identical with the known substance ${ }^{2}: \delta 8.07(\mathrm{~d}, 2 \mathrm{H}), 7.49(\mathrm{~d}, 4 \mathrm{H}), 7.04(\mathrm{~d}, 4 \mathrm{H})$, and $6.96(\mathrm{~d}, 2 \mathrm{H})$; $m / e: 450,448,446$ in 1:2:1 ratio.

2. Eberson, L.; Hartshorn, M. P.; Svensson, J. A. Acta Chem. Scand., 1997, 51, 279

Halogen dance with 4-Amino-4',4'-dibromotriphenylamine (4c). To a $10 \mathrm{~mL}$ flask were added 3 (0.190 g, $0.425 \mathrm{mmol})$ and tin (0.127 g, $1.07 \mathrm{~g}$-atom). Acetic acid (4 mL) was added and the solution immediately turned pale yellow. The flask was heated to reflux for 8 hours, after which the orange/red crystals of $\mathbf{2}$ had disappeared and a white precipitate had formed in their place. The reaction mixture was transferred to a $250 \mathrm{~mL}$ separatory funnel with $5 \mathrm{~mL}$ of water and $20 \mathrm{ml}$ of $\mathrm{CH}_{2} \mathrm{Cl}_{2}$. The mixture was shaken with $200 \mathrm{~mL}$ of $0.1 \mathrm{M} \mathrm{NaOH}$ until all of the precipitate had disappeared. The organic layer was pale yellow in color. It was separated and washed with $2 \times 100 \mathrm{~mL}$ of water, dried over $\mathrm{MgSO}_{4}$, and evaporated to produce a yellow-brown mixture, crude yield $0.144 \mathrm{~g}$. GC-MS indicated the mixture to contain five components (in order of retention time): (a) 4-aminotriphenylamine (4a) (4\%), (b) 4-amino-4'-bromotriphenylamine (4b) (6\%), (c) 4-amino-4',4"-dibromotriphenylamine (4c) (42\%, (d) a compound isomeric with 4c, probably 4-amino-3,4'-dibromotriphenylamine (4d) (13\%), and 4-amino-3, 4',4"'tribromotriphenylamine (4e) (32\%). The amines readily darkened in air and decomposed upon attempted chromatography on silica and were therefore too labile to permit separation. The mixture was moderately stable if stored under nitrogen in the refrigerator immediately upon preparation. When the reduction was carried out at $75^{\circ} \mathrm{C}$ for 1 hour, then 9 hours at $65^{\circ} \mathrm{C}$, the product mixture consisted of $\mathbf{4 a}(1 \%), \mathbf{4 c}(87 \%)$, and the putative $4 \mathbf{e}(12 \%)$. 
Diazotization of the mixture of amines produced at $75^{\circ} \mathrm{C}$. In a $25 \mathrm{~mL}$ round bottom flask were placed $0.184 \mathrm{~g}$ of the mixture of amines produced by reduction of 3 at $75^{\circ} \mathrm{C}$ together with $48 \% \mathrm{HBF}_{4}(2 \mathrm{~mL}, 15.4 \mathrm{mmol})$ and $1 \mathrm{~mL}$ of water. The flask was cooled to $0^{\circ} \mathrm{C}$ in an ice bath and equipped with a stir bar. A solution of $\mathrm{NaNO}_{2}(0.200 \mathrm{~g}, 2.90$ $\mathrm{mmol}$ ) in $2 \mathrm{~mL}$ of water was cooled to $0^{\circ} \mathrm{C}$ and added dropwise with stirring. A small amount of gas evolution was observed during addition. The flask was covered with aluminum foil to exclude light and stirred for 5 hours as it slowly warmed to room temperature. An additional solution of $\mathrm{NaNO}_{2}(0.100 \mathrm{~g})$ in $0.5 \mathrm{~mL}$ of water was cooled to $0^{\circ} \mathrm{C}$ and slowly added to the reaction mixture, again with some gas evolution. A spatula was used to crush and scrape the remaining starting material from the walls of the flask. The mixture was again cooled to $0^{\circ}$ in ice. A second portion of $\mathrm{NaNO}_{2}(0.100 \mathrm{~g})$ in 0.5 $\mathrm{mL}$ was added. The mixture was allowed to warm to room temperature and stirred for 20 hours until none of the starting material remained. Suspended in the orange solution was a clay-colored precipitate. The mixture was cooled to $0^{\circ} \mathrm{C}$ and filtered by suction. The contents of the flask were rinsed onto the filter with three $4 \mathrm{~mL}$ portions of ice-cold $4 \%$ $\mathrm{HBF}_{4}$. The clay-brown precipitate, 4-diazonia-4',4"'-dibromotriphenylamine (5) plus congeners, was left on the filter paper 20 minutes to dry and then stored in a vial under nitrogen at $4^{\circ} \mathrm{C}$, crude yield $0.301 \mathrm{~g}$. A weighed sample was heated to above $200^{\circ} \mathrm{C}$ to afford a mixture of aryl fluorides; Analysis of the mixture by GC-MS indicated the products to be 4-fluoro-4',4"'-dibromotriphenylamine (65\%), 4-fluorotribromotriphenylamine (20\%), and 3,4,4'-tribromotriphenylamine (15\%). From the weight of the mixture of fluorides, the actual yield of diazonium salts was estimated as $85 \%$.

4-Aminotriphenylamine (4a). 4-Nitrotriphenylamine $(0.173 \mathrm{~g})$ was reduced with tin and acetic acid as described previously for $\mathbf{3}$ to afford 4-aminotriphenylamine ${ }^{2}$ as pale brown crystals, $0.152 \mathrm{~g}$ (98\% yield), homogeneous by GC-mass spectrometry.

3. Cauquis, G.; Delhomme, H.; Serve, D. Tetrahedron Lett. 1972, 1965. 
Diazotization of 4-Aminotriphenylamine. Diazotization of 4-aminotriphenylamine $(0.047 \mathrm{~g})$ was carried out as described previously for the mixture of polybromotriphenylamines to afford the corresponding diazonium salt as an orange-brown solid, crude yield $0.040 \mathrm{~g}$ ). Pyrolysis afforded a mixture which was shown by GC-mass spectrometric analysis to consist of 4-fluorotriphenylamine ${ }^{4}(99 \%)$, triphenyamine $(0.5 \%)$, and $4-$ aminotriphenylamine $(0.5 \%)$.

4. Pombrik, S. I.; Kravtsov, D. N.; Kvasov, B. A.; Fedin, E. I. J. Organomet. Chem. 1977, 136, 185.

Attachment of triphenylamines to carbon fiber electrodes. Carbon fibers were obtained by unraveling WCA graphite cloth \#X2014 ${ }^{5}$ to obtain strands $c a 1 \mathrm{~mm}$ in diameter. Preparative scale electrolyses employed a $1 \mathrm{~cm}^{2}$ portion of the cloth itself. The diazonium salt was dissolved in water to afford a $2 \mathrm{mM}$ solution. Cyclic voltammetry was carried out with the carbon electrode as a cathode; the counter electrode was a platinum wire and the reference electrode was a silver wire immersed in $0.1 \mathrm{M} \mathrm{AgNO}_{3}$ in $\mathrm{CH}_{3} \mathrm{CN}$ [the potential of this electrode is $+0.35 \mathrm{~V}$ vs $\mathrm{SCE}^{6}$ ]. An irreversible wave for reduction of the diazonium moiety was observed at $-0.37 \mathrm{~V}$. The wave decreased upon successive cycles. Attachment of the triphenylamine nucleus was carried out by a single chronoamperometric potential step from -0.2 to $-0.6 \mathrm{~V}$. The current decreased rapidly and smoothly $(300 \mathrm{sec})$. The electrode was then washed with aqueous alkaline solution and acetonitrile to remove unattached adsorbed species.

5. (a) Hand, R.; Carpenter, A. K.; O’Brien, C. J.; Nelson, R. F. J. Electrochem. Soc. 1972, 119, 74; (b) Carbon Products Div., Union Carbide Corp.

6. Fry, A. J.; Touster, J. J. Org. Chem. 1986, 51, 3905. 
Representative preparative electrolysis. A $200 \mathrm{~mL}$ crystallizing dish was fitted with a machined Teflon top containing (a) a counter electrode compartment consisting of a medium fritted disc and $50 \mathrm{~mL}$ of methanol/0.1 $\mathrm{M} \mathrm{LiClO}_{4}$, (b) reference electrode, (c) a platinum wire attached to a $1 \mathrm{~cm}^{2}$ modified electrode, and (d) nitrogen purge. A solution consisting of $100 \mathrm{mg}$ of 1,2-bis-trimethylsilyl-1,2-diphenylethane (5) in $100 \mathrm{~mL}$ of methanol/0.1 $\mathrm{M} \mathrm{LiClO}_{4}$ was added to the cell, together with $1 \mathrm{gm}$ of solid $\mathrm{NaHCO}_{3}$ to neutralize acid formed during electrolysis. Not all of the silane dissolved initially. The cell was connected to the potentiostat and controlled potential electrolysis was carried out until the electrolysis current (30 mA initially) had decayed to a value of $1 \mathrm{~mA}$. The electrolysis solution was poured into water, extracted with $\mathrm{CH}_{2} \mathrm{Cl}_{2}$, dried over $\mathrm{Na}_{2} \mathrm{SO}_{4}$, and evaporated to afford $65 \mathrm{mg}$ ( $87 \%$ yield) of a clear oil, shown by gc-mass spectrometry to consist of a 1:2 mixture of 1,1-dimethoxy-2,2-diphenylethane (7) and meso and $d l$-1,2-dimethoxy-1,2-diphenylethane (6). 